\title{
UTJECAJ TERORIZMA NA SIGURNOST JAVNOG PRIJEVOZA U EUROPI
}

\author{
Ante Vuletić ${ }^{10}$, Lucijan Horak ${ }^{11}$ \& Marija Jurčevićc ${ }^{12}$
}

UDC / UDK: 323.28:656.121(4)

JEL classification / JEL klasifikacija: R41

DOI: https://doi.org/10.22598/pi-be/2021.15.2.61

Preliminary report / Prethodno priopćenje

Received / Primljeno: September 30, 2021 / 30. rujna 2021.

Accepted for publishing / Prihvaćeno za tisak: November 25, 2021 / 25.

studenog 2021.

\section{Sažetak}

Terorizam predstavlja jednu od metoda za postizanje određenih političkih ciljeva pri čemu se isti ostvaruju na temelju nasilja, kriminalnih aktivnosti te ugrožavanja širih društvenih skupina. Posljednjih dvadesetak godina javni prijevoz je postao područje od posebnog interesa teroristima zbog toga što ga koriste milijuni ljudi svakodnevno, a teško je omogućiti visoki stupanj sigurnosti na svim dijelovima. Visok stupanj zaštite u javnom prijevozu je teško osigurati na svim dijelovima sustava, a da pri tome isti ostane korisnicima lako dostupan. Za razliku od zračnih luka gdje postoje kontrolne točke, na autobusnim $i$ željezničkim stanicama ne postoje preduvjeti za uspostavu visokog stupnja sigurnosti. U svrhu ostvarivanja cilja rada, provedena je analiza dosad provedenih istraživanja koja su u fokusu imala terorističke napade te je provedeno primarno istraživanje. Bitno je raditi na implementaciji sigurnosnih mjera jer upravo one mogu otežati provedbu terorističkih aktivnosti, ali i povećati vjerojatnost da teroristi budu otkriveni i identificirani.

Ključne riječi: javni prijevoz; terorizam; učinak; sigurnost; Europska unija.

\footnotetext{
*This paper is based on the master thesis titled "Utjecaj terorizma na sigurnost javnog prijevoza u Europi” written by Lucijan Horak (https://repozitorij.efzg.unizg.hr/islandora/object/efzg\%3A6965)

10 Ante Vuletić, PhD, Associate Professor, Faculty of Economics and Business, University of Zagreb, Croatia, E-mail: avuletic2@net.efzg.hr

${ }^{11}$ Lucijan Horak, mag.oec., Trade Marketing Asisstant at Bolton Croatia Ltd., E-mail: lucijan.h@gmail.com

${ }^{12}$ Marija Jurčević, PhD, Postdoctoral researcher, Faculty of Economics and Business, University of Zagreb, Croatia, E-mail: mjurcevic@efzg.hr
} 


\section{UVOD}

Terorizam stvara znatne troškove u međunarodnim poslovnim odnosima u svim fazama. Svijest o opasnosti i prisutnosti rizika od terorizma jača te veliki broj međunarodnih poduzeća već koristi različite mehanizme zaštite od terorističkog rizika kako bi povećao sigurnost svoje imovine i zaposlenika te očuvao kontinuitet međunarodnog poslovanja. Posljednjih dvadesetak godina javni prijevoz postao je područje od posebnog interesa teroristima ponajprije zbog činjenice da ga svakodnevno koriste milijuni ljudi. Dobrobit javnog prijevoza za građane i društvo očituje se u činjenici da javni prijevoz ruši socijalne i kulturne barijere između ljudi u svakodnevnom životu (Stjernborg i Mattisson, 2016). Napadi na javni prijevoz izazivaju velike poremećaje i uzbunu, a što predstavlja tradicionalne ciljeve terorizma. Izvođenje terorističkih aktivnosti u sektoru javnog prijevoza društvu može nanijeti velike štete i s odmakom, jer prijašnja iskustva pokazuju kako se nakon napada u javnom prijevozu veliki broj korisnika odlučuje koristiti druge oblike prijevoza ili u konačnici minimiziraju korištenje usluga u javnom prijevozu (Litman, 2005). Upravo je promjena ciljanja od strane terorista, koja se dogodila u prošlih desetak godina, učinila javna mjesta (trgovački centri, robne kuće, javna prijevozna sredstva) poželjnim mjestima za provedbu napada (Gaibulloev, Sandler i Santifort, 2012).

Sukladno ranije navedenom predmet analize ovog rada je sigurnost u javnom prijevozu te analiza utjecaja terorističkih aktivnosti na sigurnost u javnom prijevozu, ali i na stavove korisnika prema korištenje usluga u javnom prijevozu. U svrhu ostvarivanja cilja rada, provedena je analiza sekundarnih podataka prikupljenih iz relevantnih domaćih i inozemnih znanstvenih i stručnih časopisa te knjiga. Dodatno je provedeno i primarno istraživanje u Republici Hrvatskoj kako bi se utvrdio stav korisnika o sigurnosti u sustavu javnog prijevoza. Rad je strukturiran u pet poglavlja. Nakon uvodnog dijela, u drugom poglavlju pobliže se objašnjava javni prijevoz te sigurnost u istome, kao i terorizam te direktni i indirektni učinci terorizma. Pregled postojećih istraživanja u čijem su fokusu terorističke aktivnosti te sigurnost $\mathrm{u}$ javnom prijevozu, predmet je analize trećeg poglavlja. Instrument korišten u empirijskom istraživanja, kao i rezultati te ograničenja provedenog istraživanja izneseni su $u$ četvrtom poglavlju. Peto poglavlje donosi zaključna razmatranja.

\section{KARATERISTIKE JAVNOG PRIJEVOZA I TERORIZMA}

\subsection{Općenito o javnom prijevozu i sigurnosti u javnom prijevozu}

Javni prijevoz je usluga prijevoza koja je dostupna svim građanima pod jednakim uvjetima. Prema Zakonu o prijevozu u cestovnom prometu (NN 41/2018) javni prijevoz je cestovni prijevoz putnika ili tereta koji je pod istim uvjetima dostupan svim korisnicima prijevoznih usluga i koji se obavlja u komercijalne svrhe, radi ostvarenja dobiti od strane prijevoznika. Gradski prijevoz putnika obuhvaća organizirani javni prijevoz putnika u gradovima s više od 40000 stanovnika, a koji obavljaju poslovni subjekti koji se bave gradskim prijevozom putnika (tramvajima i autobusima) (Državni 
zavod za statistiku, 14.05.2021.). Glavne značajke javnog prijevoza su kupnja voznih karata te vozila koja prometuju po unaprijed određenim voznim redovima s utvrđenim stajalištima za prihvat i iskrcaj putnika. Primjeri javnog prijevoza uključuju gradske autobuse, trolejbuse, tramvaje (ili laku željeznicu) i putničke vlakove, brzi tranzit (metro/podzemna željeznica itd.) i trajekti (McLeod, 2017).

Motiv za pružanje usluge javnog prijevoza najčešće je organizacija prijevoza ljudima koji nisu u mogućnosti koristiti automobil zatim smanjenje gužvi, korištenje javnih zemljišta i smanjenje štetnih emisija automobila. U odnosu na druge oblike prijevoza, javni prijevoz je siguran obzirom na nizak stupanj rizika od nesreća i na niske stope kriminala. Stopa ozljeda i smrtnosti za javni prijevoz otprilike je jedna desetina automobilskih putovanja. Javni prijevoz ima tendenciju niže ukupne stope kriminala od putovanja automobilom, a poboljšanja u javnom prijevozu mogu pomoći u smanjenju ukupnog rizika od kriminala primjerice poboljšanjem nadzora i ekonomskih prilika za rizične populacije (Litman, 2016). Važna društvena uloga javnog prijevoza očituje se i u tome da je svim društvenim skupinama omogućen prijevoz, a ne samo onima s vozačkom dozvolom i pristupom automobilu.

Putnici, kao predmet prijevoznog procesa su zahtjevni, a očekuju i traže udobnost, sigurnost, redovitost, učestalost, brzinu te ekonomičnost. Najveći zahtjev putničkog prijevoza je sigurnost. Problemu sigurnosti u javnom prijevozu potrebno je pristupiti sa preventivne i represivne strane i to od strane svih institucija nadležnih za javni prijevoz (zaštita.info, 27.02.2019.). Uspostava sigurnog javnog prijevoza predstavlja jedan od najvažnijih zadataka Europske unije, a taj zahtjev je ključna briga ne samo Unije, već i bilo kojeg transportnog sustava u svijetu (European Commission, N/A). U mnogim razvijenim državama Europe i svijeta putovanje željeznicom deset puta je sigurnije od putovanja automobilom, a trend povećanja sigurnosti se nastavlja (Zavada i sur., 2002). Poznato je kako je strah od kriminala široko rasprostranjena pojava koja utječe na percepciju sigurnosti javnog prijevoza. Pogotovo kada su u pitanju mladi ljudi koji često zaobilaze korištenje javnog prijevoza zbog predrasuda. Tako su rezultati istraživanja provedenog u Velikoj Britaniji potvrdili kako bi čak dodatnih 10,5\% željezničkih putovanja bilo generirano kada bi se ljudi osjećali sigurnije kad putuju ili dok čekaju na stanicama, dok su u Americi potvrdili kako bi većina vozača automobila u unutrašnjosti Los Angelesa koristila javni prijevoz kad bi bio sigurniji i čišći (Currie, Delbosc i Mahmoud, 2013). Potencijalne sigurnosne ugroze povezane s javnim prijevozom predstavljaju ozljede uzrokovane infrastrukturom (npr. stepenice, pokretne stepenice, platforme, rampe), nasilni zločin (npr. seksualni prijestupi, napadi nožem, terorizam, krađe), nenasilni kriminal (npr. antisocijalno ponašanje, vandalizam, uporaba droga, neovlašten pristup, pijanstvo), ili čak infekcije ili virusi. Težnja za sigurnim javnim prijevozom postoji već desetljećima. Bez obzira na nastojanja svih dionika još uvijek postoji nedostatno znanja o tome kako percepcija sigurnosti putovanja može utjecati na percepciju putnika o pristupačnosti. Percepcija sigurnosti putovanja ovisi o kvaliteti usluge, a što je veća percepcija kvalitete usluge, putnici se osjećaju sigurnije (Friman, Lättman i Olsson, 2020).

U daljnjem razvoju javnog prijevoza potrebno je prihvatiti dugoročnu perspektivu, uključujući kontinuirano poboljšanje kvalitete usvojeno prema zahtjevima 
pojedinaca i njihovim potrebama (Friman, Lättman i Olsson, 2020). Sigurnost putnika u javnom prijevozu jest uvjet bez kojega se ne može pružati usluga javnog prijevoza te je sigurnost definirana i određena regulatornim okvirom kako na području Europske unije tako i u okviru nacionalnih propisa kojima se reguliraju određene vrste prijevoza. U Republici Hrvatskoj u Zakonu o cestovnom prijevozu određeno da je prijevoznik dužan brinuti se za sigurnost putnika kao i u Zakonu o sigurnosti prometa na cestama (NN 67/08, 48/10, 74/11, 80/13, 158/13, 92/14, 64/15, 108/17, 70/19, 42/20). Visoka razina sigurnosti prijevozne usluge temeljna je pretpostavka atraktivnosti sustava javnog prijevoza putnika. Obzirom na brojnost putnika, gustoću putničkog prometa, često velike gužve, postoji visoka razina osjetljivosti sustava javnog prijevoza na kriminalne aktivnosti i posljedično zahtijeva odgovarajuću zaštitu sustava. Putnici traže osjećaj sigurnosti i zaštićenosti. Različiti oblici antisocijalnog ponašanja, vandalizma i terorističkih napada mogu nanijeti štetu sustavu javnog prijevoza, putnicima, osoblju te imovini prijevoznika (Rajsman, 2017). Sigurnost je sastavni dio koji doprinosi kvaliteti transportne usluge sa posebnim naglaskom na brojne aspekte sigurnosti kao što su upravljački, tehnološki i operativni.

Tijekom posljednjih godina terorizam je postao stvarnost u mnogim europskim zemljama predstavljajući prijetnju našem načinu života. Teroristički su akti opetovano ciljali nezaštićene javne prostore poput urbanih središta, prometnih čvorišta, mjesta za rekreaciju, trgovačkih centara, pješačkih zona, tržnica na otvorenom, koncertnih dvorana i gradskih trgova što se vidi u napadima u, na primjer, Barceloni, Berlinu, Bruxellesu, Londonu, Manchesteru, Nici i Stockholmu (EUROPOL, 2020). Javni prijevoz jedna je od čestih meta terorističkih aktivnosti te se je u skladu s Akcijskim planom za potporu zaštiti javnih prostora (European Commission, 2018) Europska komisija obvezala podržati zemlje EU u nastojanju da se takvi napadi preveniraju imajući na umu da je takva prevencija i zaštita javnih prostora prvenstveno u nadležnosti država članica. Potrebno je kontinuirano raditi na osmišljavanju rješenja za prevenciju i ublažavanje učinaka terorističkih aktivnosti kroz kontinuirano jačanje regulatornog okvira, predlaganje smjernica za zemlje EU, gradske vlasti i operatore. Financiranje od strane Europske unije pruža još jedan način podrške državama članicama u zaštiti javnih prostora, oslanjajući se na stručnost i najbolju praksu u državama članicama i jačanju prekogranične suradnja. Sve mjere osiguranja moraju se provoditi što diskretnije kako bi se minimalizirao njihov utjecaj na društvo i izbjeglo stvaranje sekundarnih ranjivosti. Treba voditi računa kako terorističke organizacije kontinuirano pokušavaju inovirati svoje tehnike i modificiraju svoje načine djelovanja stoga se očekuje od Europske unije te država članica da budu jednako inovativne u odgovoru, iskorištavanju tehnologije i udruživanju stručnog znanja i iskustva radi otkrivanja i ublažavanja novih prijetnji (European Commission, 2018).

\subsection{Pojmovno određenje i karakteristike terorizma}

Potreba za definiranjem terorizma u Europi sa ciljem utvrđivanja jasnog pravnog okvira pojavila se 2001. godine kada je Europska unija ozbiljno započela proces definiranja samog terorizma. Pravna osnova već je bila u Ugovoru iz Maastrichta, izmijenjena Amsterdamskim ugovorom (European Commision, 10.11.1997). Jedan od ciljeva Unije, kako je deklarirano u članku 29. Ugovora, jest „pružiti svojim građanima visoku razinu sigurnosti u području slobode, sigurnosti i pravda '; nadalje, ovaj se cilj 
želi postići „razvojem zajedničkog djelovanja među državama članicama "na polju [između ostalog] $i$,, pravosudne suradnje u kaznenim stvarima”. U članku 31. istog Ugovora izričito se spominje da takva zajednička radnja uključuje ,postupno usvajanje mjera kojima se uspostavljaju minimalna pravila koja se odnose na sastavne elemente kaznenih djela i kazne u područja organiziranog kriminala, terorizma i ilegalne trgovine drogom". Na temelju tih odredbi, Europski parlament usvojio je Rezoluciju o ulozi Europske unije u borbi protiv terorizma (European Commission, 27.11.2001.), pozivajući Vijeće da utvrdi minimalna pravila koja se odnose na sastavne elemente terorističkih činova, kao i sankcije koje će se izreći.

Bez obzira na različitu percepciju terorizma i SAD i Europska unija terorizam definiraju na sličan način. Tako se u literaturi navodi analiza američkih definicija i definicija Vijeća Europske unije koje sadržavaju riječi nasilje i politika te se zaključuje kako su i SAD i EU suglasni da je terorizam uporaba nasilja (terora) radi ostvarenja političkih ciljeva (Prodan, 2014). Terorizam je čin oštećenja ili uništavanja civilnog života ili oštećenja civila ili vladine imovine bez izričitog dopuštenje određene vlade da utječe na političke ciljeve. Prema definiciji Globalnog indeksa terorizma (Global Indeks Terorism, GTI, https://www.visionofhumanity.org/maps/global-terrorism-index/\#/), terorizam se definira kao namjerno nasilno djelovanje ili prijetnja nedržavnog aktera sa ciljem uništavanja društvenog dobra.

U pravu Europske unije, Direktivom EU 2017/541 o borbi protiv terorizma, koju su sve države članice EU bile obvezne prenijeti u svoje nacionalno zakonodavstvo do 8 . rujna 2018. godine teroristička djela su definirana kao određena namjerna djela koja, s obzirom na njihovu prirodu ili kontekst, mogu ozbiljno naštetiti nekoj državi ili međunarodnoj organizaciji, počinjena s ciljem ozbiljnog zastrašivanja stanovništva, ili prisiljavanje vlade ili međunarodne zajednice za izvođenje ili suzdržavanje od izvođenja bilo kojeg djelovanja, ili ozbiljno destabilizirajući ili uništavajući temeljne političke, ustavne, ekonomske ili socijalne strukture neke države ili međunarodne organizacije (EUROPOL, 2020).

Grafikon 1. Vjerski terorizam u Europskoj uniji, 2014.-2019.

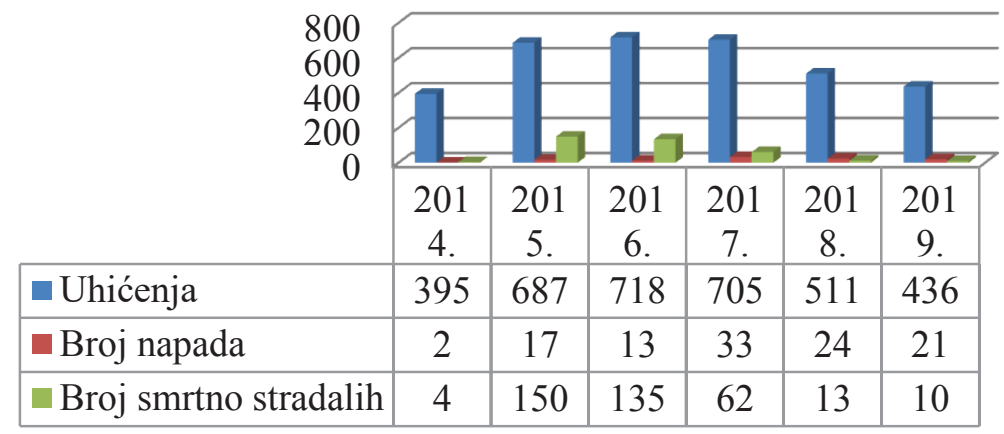

Izvor: izrada autora prema Europski parlament (03.11.2020.). Terorizam u EU-u: Napadi, stradanja i uhićenja u 2019 . 
Kao što je vidljivo na grafikonu 1, broj terorističkih napada je i u 2019. godini nastavio padati u odnosu na godinu ranije. Ukupno je u Europi u 2019. godini izvedeno 119 terorističkih napada, od čega je njih 21 bio u organizaciji džihadista. No, bitno je istaknuti kako su sve smrtno stradale osobe bile upravo vezane za džihadističke napade (Europski parlament, 03.11.2020.).

Tablica 1. Broj džihadističkih terorističkih napada u Europskoj uniji, 2017.-2019.

\begin{tabular}{|l|c|c|c|}
\hline & $\mathbf{2 0 1 7}$ & $\mathbf{2 0 1 8 .}$ & $\mathbf{2 0 1 9 .}$ \\
\hline Izvršeni napadi & 10 & 7 & 3 \\
\hline Neuspješni napadi & 12 & 1 & 4 \\
\hline Spriječeni napadi & 11 & 16 & 14 \\
\hline UKUPNO & $\mathbf{3 3}$ & $\mathbf{2 4}$ & $\mathbf{2 1}$ \\
\hline
\end{tabular}

Izvor: Europski parlament (03.11.2020.). Terorizam u EU-u: Napadi, stradanja i uhićenja u 2019..

U tablici 1 se može uočiti kako je broj spriječenih napada i u 2018. i u 2019. godini bio dvostruko veći od broja izvršenih ili neuspjelih napada.

\subsection{Direktni i indirektni učinci terorističkih aktivnosti}

Šrenje terorizma potaknulo je snažne političke reakcije u smislu protuterorističkih akcija i pokretanja preventivnih programa. Razumijevanje ekonomskog učinka terorizma pruža značajnu osnovu za procjenu raspodjele financijskih sredstava za protuterorističke programe i aktivnosti. Mjerenje razmjera i troškova terorizma ima važne implikacije za procjenu njegovih direktnih i indirektnih učinaka na ekonomsku aktivnost (Bardwell i Mohib, 2021). Terorizam, kako je već prije objašnjeno, je djelovanje koje je usmjereno na izvršavanje ilegalnih prijetnji, nasilja i straha radi postizanja određenih ciljeva. Izvršavanjem takvih ciljeva postižu se u najvećoj mjeri ekonomski troškovi, a koje je moguće podijeliti na dvije vrste, direktne i indirektne. Nastali direktni troškovi od terorizma uključuju troškove povezane s ozljedama, gubitak života, oštećenjem imovine, infrastrukture, poslovnih prostora i ostalih gubitaka. Direktni učinci terorizma kratkoročni su i lako se mjere. S druge strane postoje i troškovi indirektnog karaktera, a koji se sve intenzivnije osjećaju nakon terorističkih posljedica. Indirektni troškovi nastaju na više razina, a ponajviše se očituju na ekonomskoj, financijskoj i fiskalnoj, kroz duži period. Tako nastali učinci vidljivi su u mnogim područjima te su usko povezani s mnogim kompleksnim procesima poput vanjske trgovine, tokovima kapitala, gospodarskom rastu, izravnim stranim ulaganjima, turizmu i nezaposlenosti (Akca i Ela 2017). 


\section{PREGLED LITERATURE O TERORISTIČKIM AKTIVNOSTIMA U JAVNOM PRIJEVOZU}

Sigurnost javnog prijevoza osjetljivo je pitanje koje pogađa sve sudionike prijevoza. Temeljno je pravo moći putovati bez straha da će sudionik u javnom prijevozu biti žrtva nekog oblika napada. Važno je uspostaviti da se sigurnost ostvaruje na način da putovanje ne učini neugodnim iskustvom. Teroristička djela su, srećom, rijetki događaji no javni prijevoz je jedna od čestih meta takvih aktivnosti. Koliko god takav događaj bio rijedak, rizik ostaje i otkriva ranjivosti cijelog sustava javnog prijevoza. Javni prijevoz kao kritična infrastruktura strateški je element za svaku državu te svaka vrsta terorističkog napada dovodi do opasnosti za društvo kao takvo. Europska unija čini velike napore kako bi adekvatno odgovorila na terorističke napade usmjerene na javne prostore pa tako i javni prijevoz. Trenutni status učinkovitosti zaštite kritične infrastrukture u EU nije dovoljan te države članice nisu u stanju adekvatno reagirati na promjenu uvjeta rizika i prijetnji, niti su sposobne učinkovito djelovati i rješavati probleme povezane s terorizmom (Ciganik i Balasicova, 2008).

Kao jedna od ključnih slabosti borbe protiv terorizma u radu obavještajnih agencija jest pitanje njihove sposobnosti otkrivanja i sprečavanja terorističkih aktivnosti. Predviđanja obavještajnih analitičara mogu biti $100 \%$ točna samo ako postoje $100 \%$ konkretne i određene informacije o budućim događajima. Kada primjerice terorističku grupu čini skupina od četvero ljudi, sa slobodom kretanja unutar jedinstvenog tržišta Europske unije koja ima cca. 450 milijuna stanovnika, tada je zadatak otkrivanja i prevencije gotovo nemoguć. To je bio slučaj u napadima 7. srpnja 2005. i 21. srpnja 2005. godine na londonski sustav javnog prijevoza gdje su bombaši bili dio populacije od otprilike 7,47 milijuna. Ni njihove obitelji ni susjedi nisu sumnjali da planiraju bilo kakva nedjela, a kamoli teroristički napad (Segell, 2006). Danas je broj ljudi koji se koriste podzemnom željeznicom u Londonu još i veći te samo područje londonskog metroa obuhvaća populaciju od 9,43 milijuna ljudi (https://www.macrotrends.net/cities/22860/london/population, 2021). Pregledom istraživanja utvrđeno je kako u posljednje vrijeme karakteristike onih koji su počinili ozbiljne terorističke zločine nisu direktno povezane sa sustavom izravnog zapovijedanja određene terorističke organizacije (npr. IS), već su vrlo često pod utjecajem političke propagande terorističkih organizacija na društvenim mrežama (Park, 2020). Pitanje antiterorističke zaštite sustava metroa posljednjih desetljeća znatno se pogoršalo. Jedan od uzroka pogoršanja jest opći rast terorističke prijetnje u svijetu. Počinjen je cijeli niz terorističkih napada u metro sustavima raznih zemalja svijeta, uključujući Britaniju, Rusiju, SAD, Japan i Francuska (Global Terorism Database, 2021). Kako bi se moglo poduzeti učinkovite mjere suzbijanja takvih napada potrebno je jasno poznavati trendove suvremenog terorizma, posebno na temelju sistematizacije i analize statističkih podataka o terorističkim napadima počinjenim u metro sustavima $s$ naknadnim formiranjem matrice trendova (Shvetsov i Shvetsov, 2019). U skladu s postojećim regulatornim okvirom na razini Europske unije u državama članicama potrebno je uspostaviti na nacionalnoj razini posebna vijeća za terorizam, a koja razmatraju planove, ciljeve i mjere u borbi protiv terorizma s posebnim naglaskom na javni prijevoz. Od iznimne je važnosti 
voditi računa da borba protiv terorizma ne ograničava temeljna ljudska prava te da se u svim aktivnostima poštuje načelo proporcionalnosti (European Commission, 2020).

Postoji sve veći broj radova o sigurnosti javnog prijevoza, no većina studija na ovu temu ima fokus na samo jednu vrstu sustava prijevoza ili na jedan grad. Postoji potreba boljeg razumijevanja sigurnosnih problema u različitim vrstama prijevoza, a posebno javnog prijevoza i to u različitim zemljopisnim područjima kako bi se pomoglo informirati gradske ili tranzitne agencije u iznalaženju modaliteta sigurnosti javnog prijevoza (Duduta i sur., 2014). Javni prijevoz pruža uslugu mobilnosti za korisnika te ima širok utjecaj na sustav. Istim treba upravljati na način kako bi se postigao učinkovit i djelotvoran sustav prijevoza. Da bi se to postiglo, potrebno je izmjeriti kvalitetu usluge kao način procjene njezine izvedbe. Europska komisija predložila je hijerarhiju odrednica kvalitete u javnom prijevozu u Europi. U toj hijerarhiji determinanti kvalitete, sigurnost je definirana kao stvarni stupanj osiguranja od zločina ili nesreće i rezultira osjećajem sigurnosti. Klasifikacija osiguranja sastoji se od tri aspekta (European Commission. QUATTRO Final Report: Synthesis and Recommendations, 1998):

1. Osiguranje od kriminalnih aktivnosti te eventualnog počinjenja zločina. To podrazumijeva prisutnost osoblja/policije, rasvjeta, vidljivo praćenje, identificirane točke pomoći.

2. Osiguranje od nesreće kroz prisutnost/vidljivost, izbjegavanje/vidljivost opasnosti, aktivno osiguranje od strane osoblja.

3. Percepcija sigurnosti od strane javnosti koja se provodi raznim mjerama kao što je kontinuirana provjera sigurnosnih mjera, „ovladavanje mrežom”; informiranje javnosti o svim provedenim i budućim sigurnosnim mjerama uz njihovu aktivnu ulogu.

U jednom od istraživanja (Useche i sur., 2018) prikazana je značajna važnost opće sigurnosti javnog prijevoza, koje se fokusira upravo na radne uvjete i sigurnost ljudi koji su u izravnom kontaktu s javnim prijevozom. U sklopu istoga analizirani su i svakodnevni uvjeti i psihološki faktori koji utječu na čovjeka, a posebice na profesionalne vozače u javnom prijevozu. Profesionalni vozači kao bitni čimbenici u izvođenju funkcije javnog prijevoza imaju iznimno važnu ulogu u sigurnosti javnog prijevoza. Njihovo psihofizičko stanje i stabilnost ključni su čimbenik prevencije odnosno pravovremenog djelovanja u slučaju terorističke aktivnosti. Uvjeti rada i psihosocijalni faktori rada imaju važnu ulogu u dobrobiti i performansi profesionalnih vozača, uključujući one koji rade na terenu javnog prijevoza. Cilj spomenutog istraživanja bio je utvrditi povezanost između opterećenja posla i operativnog stanja performanse vozača javnog prijevoza i usporediti izloženost s psihosocijalnim rizikom na radu tri različite vrste prijevoznika: taksisti, vozači gradskih autobusa i vozači međugradskih autobusa. Istraživanje je provedeno na uzorku od 780 profesionalnih vozača te je obuhvatilo tri prijevoznička poduzeća u Bogoti (Kolumbija). Rezultati su potvrdili značajnu povezanost između mjera socijalno-radnih varijabli i ključnih pokazatelji uspješnosti kao što su prometne nesreće i kazne. Stres na poslu značajno doprinosi sigurnosti profesionalnih vozača pa time i utječe na sigurnost putnika u javnom prijevozu. Rezultati ovog istraživanja pružili su dokaze koji potkrepljuju značajan učinak opterećenja posla na performanse profesionalnog 
vozača. Utvrđene i statistički značajne razlike između taksista, vozača gradskih autobusa i međugradskih autobusa.

Studija koju su proveli Duduta i suradnici (2014) obuhvaća tzv. "površinski javni prijevoz" odnosno široko područje kategorija, u teoriji koja uključuje sve, od minibusa do regionalnih željezničkih sustava, s vrlo različitim sigurnosnim problemima na suprotnim krajevima spektra. Nalazi istraživanja jasno ukazuju da glavna sigurnosna pitanja ovise više o geometriji prolaznog koridora nego o korištenoj tehnologiji. Utvrđena su dva ključna sigurnosna problema svojstvena autobusu i željeznici, a to su zaustavna udaljenost i upravljanje sukobljenim točkama između prijevoznih sredstava. Uobičajeno je za autobuse da imaju veću brzinu kočenja te kao rezultat toga, kraće zaustavljanje od željezničkih vozila, iako to značajno varira ovisno o vrsti kočenja, tehnologiji koja se koristi, nagibu i vremenskim uvjetima (Vuchic, 2007). Kod željezničkih sustava naglasak je na signalizaciji dok su kod autobusnog prometa vozači ti koji upravljaju potencijalno opasnim situacijama.

Iako gotovo sve studije sugeriraju moguća rješenja za utvrđene probleme, ne postoji jedinstveno rješenje. Kada postoje sigurnosne procjene, one se obično temelje na podacima prikupljenim od malog broja prijevoznika, a ne na sustavnoj procjeni rješenja i mjera više prijevoznika. Ovo je ključno područje u kojem je potrebno više istraživanja, a posebice o utjecaju terorističkih aktivnosti na sigurnost javnog prijevoza kao i omogućavanju prijevoznicima procjene isplativosti različitih mjera i odabira najboljeg načina za poboljšanje sigurnosti. Neka istraživanja pokazuju da jedan od rizika za putnike u javnom prijevozu nije dok se voze prijevoznim sredstvom, već kada hodaju do i od stanice (Duduta i sur. 2012).

Trenutačno europskim vlakovima, a tu je uključen i međugradski prijevoz kao vrsta javnog prijevoza kao i prijevoz na manjim udaljenostima između gradova dnevno putuje 26 milijuna putnika, a očekuje se da će se do 2050. godine putovanje željeznicom povećati za otprilike $80 \%$. Imajući na umu stalne sigurnosne prijetnje putnici u željezničkom prometu, radnici kao i infrastruktura veliki su izazov, ali i prioritet zaštite. U Europskoj uniji postoji potreba za kreiranjem modernog sustava koji je utemeljen na procjeni rizika te uz mogućnost brze reakcije na potencijalne terorističke prijetnje uz očuvanje dostupnosti usluga kao i podizanja tih usluga na višu razinu sigurnosti. (https://eur-lex.europa.eu/legal-content/HR/TXT/?uri=CELEX\%3A52018DC0470). U svrhu postizanja zadanih ciljeva Europska Komisija je predložila cijeli niz kratkoročnih mjera kako bi se osigurala sigurnost putnika u željezničkom prometu u Uniji. Konkretne kratkoročne mjere su primjerice uspostava Platforme za sigurnost putnika u željezničkom prometu Europske unije. Kroz uspostavu Platforme želi se osigurati podrška za prikupljanje i razmjenu informacija vezanih uz sigurnost, učinkovitija zaštita usluga te uspostava usklađenih mehanizma sa svrhom usklađivanja djelovanja na nacionalnom nivou država članica. U državama članicama već postoje vježbe koje provode željezničke policijske snage koordinirane na nivou Europske unije, a predstavljaju razradu paketa mjera za borbu protiv terorizma donesenog 18. listopada 2017. godine. Nakon terorističkog napada u Madridu 2004. godine u kojem je poginulo preko 191 osoba te ozlijeđeno 1500, terorističkih napada u Londonu 2005. godine u kojem je život izgubilo preko 50 ljudi od strane bombaša samoubojica postalo je jasno da su takve vrste napada 
u javnom prijevozu postale često korištena metoda terorističkih napada u modernom društvu te se nametnula potreba za iznalaženjem učinkovitih načina prevencije i djelovanja u slučaju samog napada. Društvo u cjelini, a posebice državna nadležna tijela, inženjeri, arhitekti, antiterorističke grupe moraju raditi na ex ante zaštiti kroz procjenu rizika te dizajniranja zaštitnih mjera sa svrhom prevencije i zaštite od terorističkih aktivnosti. U podzemnoj željeznici u Londonu iznimno je dostupan pristup svakoj od 275 stanica te potencijalni napadač može putovati neopaženo kroz cijeli sustav. Jedno od ključnih mjesta prevencije i kontrole jest detekcija na ulazu u samu transportnu mrežu te kontrolne točke prijevoznih karata slično kao i kod avionskog prijevoza. Pretpostavka je da se kontrola mora provoditi na takav način da ne ometa funkciju i samu prijevoznu uslugu. Takav sustav kontrole jest skup no efikasan te se može primijeniti i na autobusni prijevoz i ostali željeznički prijevoz. Preventivne mjere uključuju procjenu rizika najslabijih točaka javnog prijevoza, detektore bombi na ulazu prilikom kontrole karata te stanicama s visokim stupnjem rizika. Pojačani sustav nadzora kamerama na svim stanicama kao i povećani broj zaštitarskog osoblja s vidljivim oznakama kao i uporaba pasa za otkrivanje eksplozivnih naprava. Preporuča se i uska suradnja nacionalnih obavještajnih službi te pojačana razmjena informacija. U prevenciji terorističkih aktivnosti ključnu ulogu imaju i inženjeri te arhitekti u dizajniranju i jačanju infrastrukture. Također su sami dizajn i organizacija sjedećih mjesta unutar prijevoznog sredstva iznimno bitni na način da je transparentno te lako dostupno za pregled $\mathrm{i}$ pronalaženje eventualno eksplozivnih naprava. Jačanje komunikacije između vozača i centralne kontrole sustava javnog prijevoza te stroža kontrola ulaska osoblja navodi se kao jedan od ključnih čimbenika u prevenciji terorističkih aktivnosti (Esper i Bond, 2005).

Ulaganja u sigurnost trebaju biti u korelaciji sa skupom identificiranih rizika, koji se mogu definirati kao umnožak vjerojatnosti i učinka određene prijetnje. Procjena rizika sastoji se od definiranja konteksta rizika, identifikacije rizika, analize rizika te evaluacije rizika što onda dovodi do sanacije rizika (Slika 1). Naravno potrebna je opsežna kontrola i analizu te komunikacija i savjetovanje. 
Slika 1. Proces upravljanja rizikom

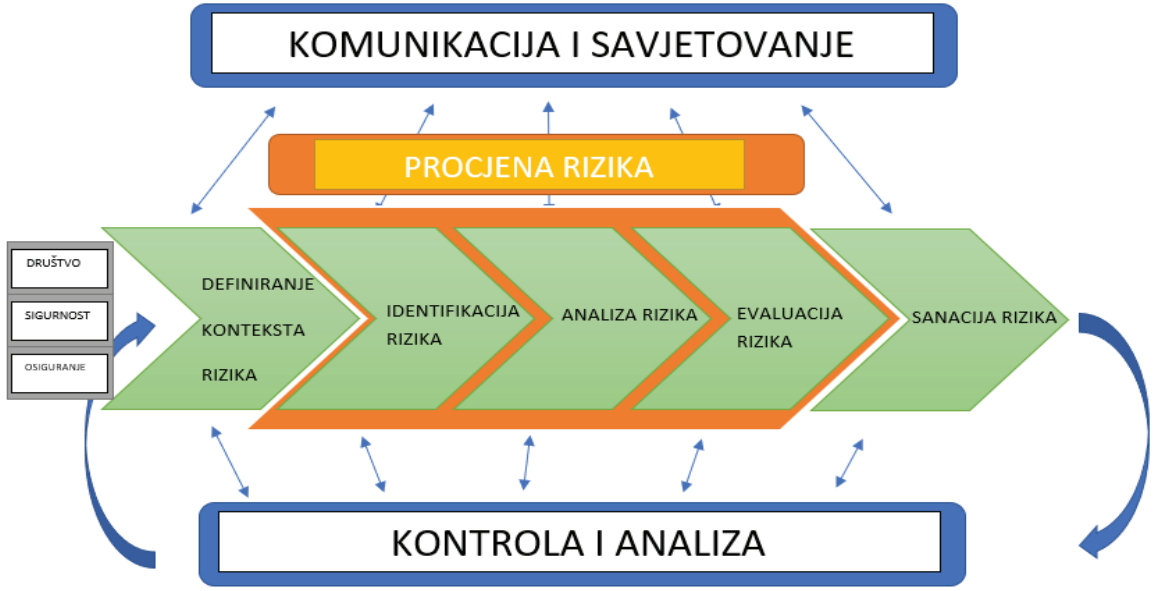

Izvor: Matsika et al. (2016)

Nastavno su u tablici 2 prikazani i projekti upravljanja rizicima sa prikazom razvijenosti metodologije procjene rizika posebno za Europsku uniju.

Tablica 2. Prikaz projekata upravljanja rizicima sa prikazom razvijenosti metodologije procjene rizika za EU

\begin{tabular}{|c|c|c|c|c|c|c|}
\hline 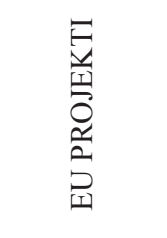 & 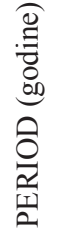 & OPIS & 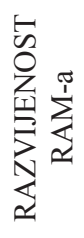 & 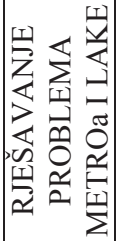 & 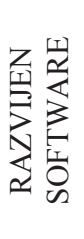 & 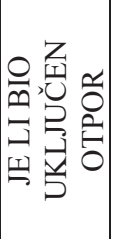 \\
\hline SECUR-ED & 3.5 & $\begin{array}{l}\text { Demonstracijski projekt pruža skup } \\
\text { protumjera za poboljšanje sigurnosti } \\
\text { gradskog prometa. }\end{array}$ & DA & NE & NE & DA \\
\hline $\begin{array}{l}\text { SECURE- } \\
\text { STATION }\end{array}$ & 3 & $\begin{array}{l}\text { Razvoj smjernica za dizajn za rješavanje } \\
\text { rizika od terorističkih napada na } \\
\text { željezničkim postajama. }\end{array}$ & DA & $\mathrm{NE}$ & DA & DA \\
\hline $\begin{array}{l}\text { SECURE- } \\
\text { METRO }\end{array}$ & 3 & $\begin{array}{|llll|}\text { Razviti potvrđeni odabir materijala } & \text { i } \\
\text { strategije } & \text { strukturnog } & \text { dizajna } & \text { za } \\
\text { izgradnju metro vozila otpornih } & \text { na } \\
\text { eksplozivne i vatrene bombe. } & \end{array}$ & $\mathrm{NE}$ & N/A & NE & DA \\
\hline
\end{tabular}




\begin{tabular}{|c|c|c|c|c|c|c|}
\hline EURACOM & 2 & 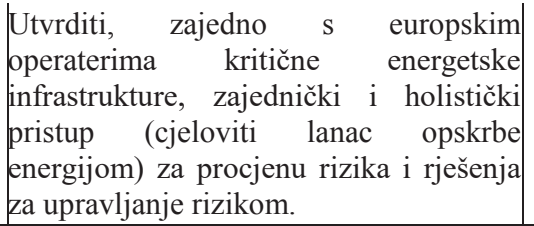 & DA & $\mathrm{NE}$ & $\mathrm{NE}$ & $\mathrm{NE}$ \\
\hline RACAM & 2 & $\begin{array}{l}\text { Razviti okvir za procjenu rizika i } \\
\text { metodologiju revizije protumjera za } \\
\text { procjenu i ublažavanje ranjivosti metroa } \\
\text { sustavi protiv potencijalnih terorističkih } \\
\text { napada. }\end{array}$ & DA & $\mathrm{NE}$ & $\mathrm{NE}$ & DA \\
\hline $\begin{array}{c}\text { COUNTER- } \\
\text { ACT }\end{array}$ & 3 & $\begin{array}{l}\text { Razvoj metodologije rizika za prometni i } \\
\text { energetski sektor od terorističkih } \\
\text { prijetnji. }\end{array}$ & DA & $\mathrm{NE}$ & $\mathrm{NE}$ & DA \\
\hline
\end{tabular}

Izvor: Matsika et al. (2016)

Analizom podataka u tablici 2 može se zaključiti da je metodologija procjene rizika $u$ velikom broju projekata razrađena kao primjerice za gradski promet, željeznički promet i sustave metro-a.

\section{ISTRAŽIVANJE UTJECAJA TERORISTIČKIH AKTIVNOSTI NA SIGURNOST JAVNOG PRIJEVOZA U EUROPI}

\subsection{Metodologija i uzorak istraživanja}

U svrhu ostvarivanja cilja rada, uz analizu sekundarnih podataka, provedeno je i primarno istraživanje. Primarno istraživanje provođeno je u prvom tjednu srpnja 2021. godine, a kao instrument istraživanja korišten je visoko strukturirani anketni upitnik. Upitnik je popunjavan online putem Google obrasca, a ukupno ga je ispunilo 99 ispitanika. Cilj provedenog primarnog istraživanja bio je utvrditi stav ispitanika glede sigurnosti javnog prijevoza s posebnim osvrtom na terorističke aktivnosti.

Anketni upitnik sastavljen je od 12 pitanja. Prva četiri pitanja bila su usmjerena na utvrđivanje karakteristika ispitanika (spol, dob, stupanj obrazovanja i visina primanja). Pet pitanja je bilo zatvorenog tipa, a istima se ispitivalo ispitanike o javnom prijevozu. $U$ 3 pitanja su ispitanici ocjenjivali ocjenama od 1 do 5 važnost određenog faktora ili stupanj slaganja s određenom tvrdnjom. Pitanja su preuzeta iz prijašnjih istraživanja (Friman, Lättman i Olsson, 2020; Wagner i Lehnigk, 2010; Currie i sur., 2013).

U istraživanju je ukupno sudjelovalo 99 ispitanika. Od ukupnog broja ispitanika njih $63,3 \%$ su osobe ženskog spola dok je ispitanika muškoga spola bilo $36,7 \%$ odnosno 36 osoba (Grafikon 2). 
Grafikon 2. Dobna i spolna struktura ispitanika

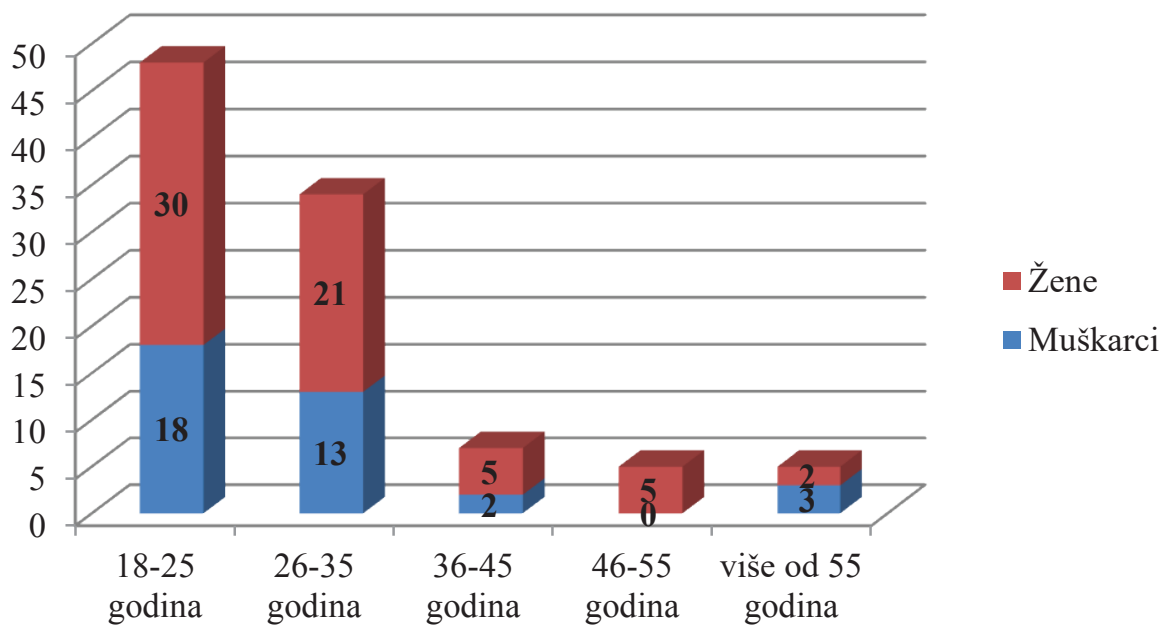

Izvor: primarno istraživanje

Najzastupljenija dobna skupina (48 osoba) u provedenom primarnom istraživanju je od 18 do 25 godina. 30,30\% ispitanika starosti od 18 do 25 godina bilo je ženskog spola, dok je muških osoba iste starosne strukture bilo 18,18\%. Sljedeća skupina po zastupljenosti je od 26 do 35 godina gdje također prevladavaju ženske osobe. Drastičan pad vidljiv je u skupini od 36 do 45 godina gdje je 5 ženskih osoba ili 5,05\% ukupnih ispitanika, dok je muškaraca u toj skupini svega dvoje. Osobe ženskog spola su u većoj mjeri pristupile ispunjavanju visoko strukturiranog upitnika (Grafikon 2).

Grafikon 3. Struktura ispitanika prema stupnju obrazovanja

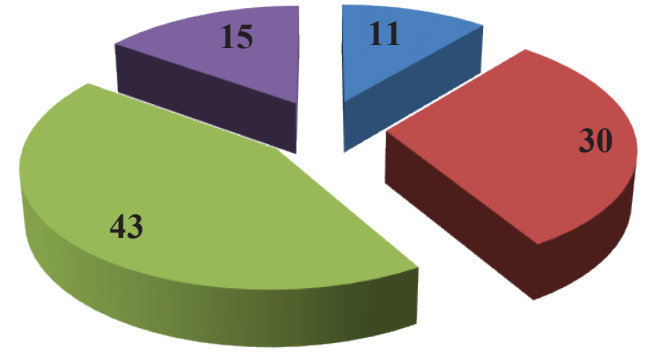

- Srednja škola

- Preddiplomski studij

Diplomski studij

- Poslijediplomski studij

Izvor: primarno istraživanje 
Od ukupno 99 ispitanika, najmanje su zastupljeni oni sa srednjoškolskim obrazovanjem, odnosno takvih je u istraživanju sudjelovalo $11(11,1 \%)$, dok je najzastupljenija skupina sa završenim diplomskim studijem odnosno pripadaju joj 43 ispitanika $(43,4 \%)$.

Grafikon 4. Prihodovna struktura ispitanika

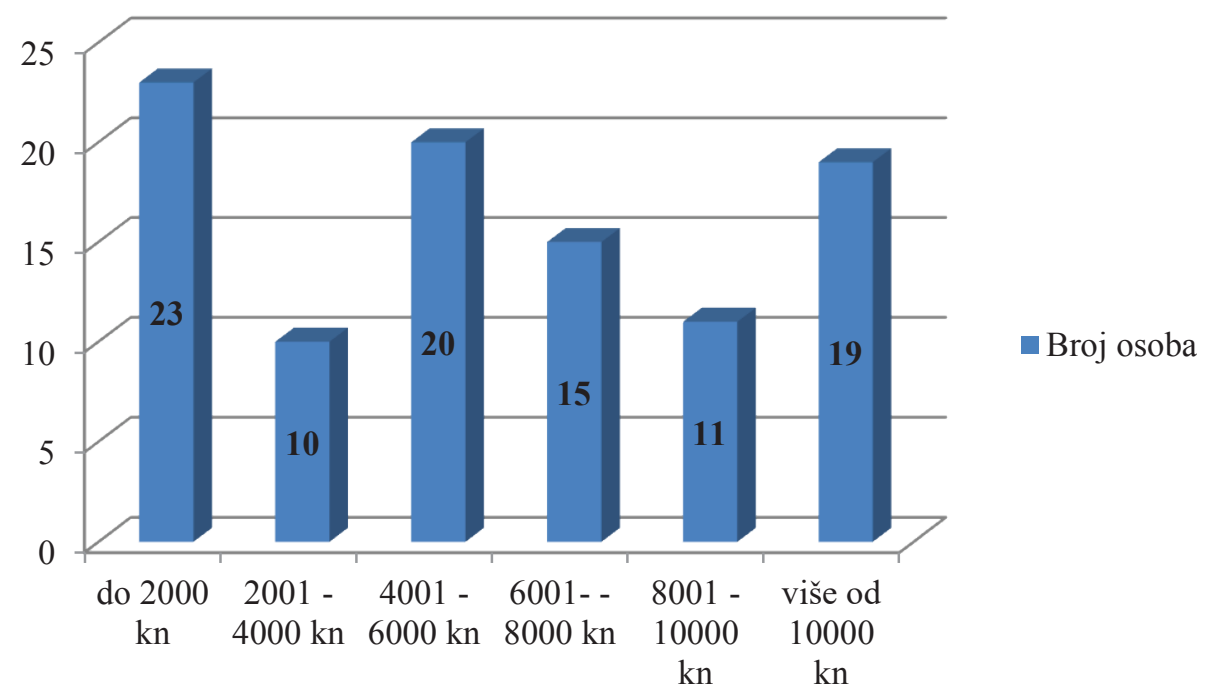

Izvor: primarno istraživanje

Struktura prihoda koje ispitanici ostvaruju kreće se u rasponu do $2.000 \mathrm{kn}$, a koje ostvaruje najviše ispitanika njih čak 23 ili 23,23\%. Prihode u rasponu od 2.001 do 4.000 kn ostvaruje 10 ispitanika ili 10,10\%. Sljedeća skupina je od 4.001 do 6.000 kn koju čini 20 ispitanika ili 20,20\%. Zatim grupa od 6.001 do $8.000 \mathrm{kn}$ sastoji se od 15 osoba ili $15,15 \%$. Od 8.001 do $10.000 \mathrm{kn}$ ima čak 11 osoba ili $11,11 \%$ te više od $10.000 \mathrm{kn}$ dohotka ostvaruje 19 ispitanika. Ako usporedimo stupanj obrazovanja ispitanika gdje je najveći postotak ispitanika sa završenim diplomskim studijem moguće je dovesti u vezu i prihode u rasponu do $2.000 \mathrm{kn}$ jer se radi o mlađoj dobnoj skupini koja je tek završila fakultet te ima ,pripravničku“ plaću.

\subsection{Rezultati istraživanja}

Jedno od pitanja u anketnom upitniku bilo je jesu li ikada ispitanici koristili usluge javnog prijevoza (npr. u Zagrebu se navedeno odnosi na gradsko-prigradsku željeznicu, TAXI službu i ZET - zagrebački električni tramvaj)? Na taj upit svi ispitanici su odgovorili potvrdno. Glede svrhe korištenja usluga javnog prijevoza, ispitanici najviše koriste javni prijevoz u svrhu odlaska i dolaska na posao $(29,6 \%)$, a zatim u svrhu odlaska u posjetu obitelji i prijateljima $(25,5 \%)$. Dio ispitanika koristi javni prijevoz kada nema 
auto i to njih $8,2 \%$. U svrhu odlaska liječniku usluge javnog prijevoza koristi $5,1 \%$ ispitanika. Svega $2 \%$ ispitanika koristi javni prijevoz za odlazak u centar grada $2 \%$. U vrlo malom postotku (1\%) ispitanici su naveli da koriste javni prijevoz i u druge svrhe odnosno u situacijama kada su primjerice pili alkoholna pića, nemogućnost parkiranja u centru grada, korištenje taxi usluge radi sigurnosti u kasnim noćnim satima i slično. Iz rezultata je vidljivo kako je korištenje javnog prijevoza u svrhu odlaska i dolaska na posao primarni razlog korištenja javnog prijevoza.

Grafikon 5. Važnost faktora koji utječu na korištenje usluga javnog prijevoza

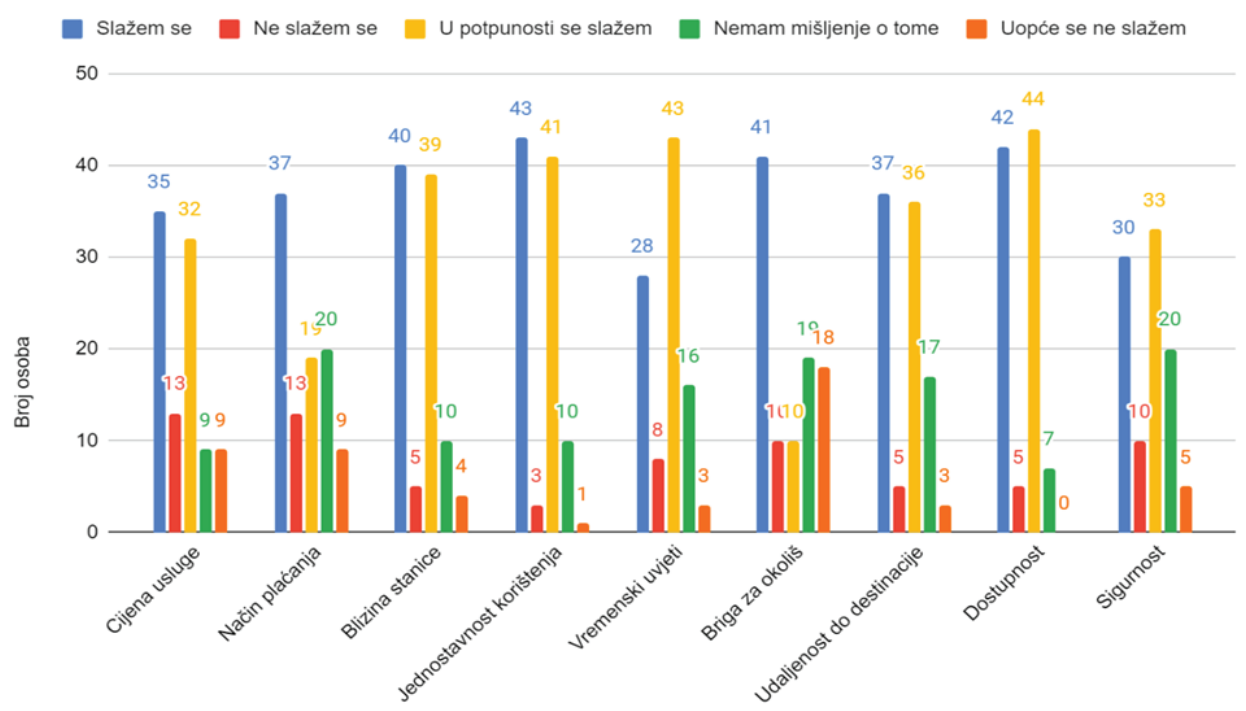

Izvor: primarno istraživanje

$\mathrm{Na}$ grafikonu 5 dan je prikaz ocjena koje su ispitanici dodijelili pojedinim faktorima koji utječu na korištenje usluga javnog prijevoza. Ispitanici su ocjenama od 1 do 5 ( 1 - u potpunosti nevažan, 5 - u potpunosti važan) ocjenjivali važnost faktora kao što su cijena usluge, način plaćanja usluge i blizina stanice. Kada se radi o cijeni usluge najviše ispitanika, njih 33, se slaže kako je ista važan faktor prilikom korištenja usluge javnog prijevoza. Način plaćanja usluge za ispitanike jest važan faktor te ju njih 37 smatra izrazito važnom. Čak 20 ispitanika nema mišljenje o načinu plaćanja kao važnom čimbeniku prilikom korištenja usluge javnog prijevoza. Analizirajući rezultate blizina stanice je vrlo važan faktor za čak 40 ispitanika, dok njih 39 istu smatra u potpunosti nevažnom. Jednostavnost korištenja usluge javnog prijevoza vrlo je važan faktor prilikom korištenja usluge javnog prijevoza, a što se najbolje ogleda u činjenici da je čak 84 ispitanika ocijenilo taj faktor kao iznimno važan ili važan. Na uslugu korištenja javnog prijevoza u velikoj mjeri kao važan faktor utječu vremenski uvjeti što potvrđuje čak 43 ispitanika koji isti smatra iznimno važnim faktorom. Ispitanici u velikoj mjeri 
iskazuju kako je briga za okoliš važan faktor koji utječe na korištenje usluge javnog prijevoza, te ih je 41 taj faktor ocijenilo kao iznimno važan. Najveći broj ispitanika (86) kao važan ili iznimno važan faktor kod korištenja usluge javnog prijevoza ocijenio je dostupnost same usluge. Sigurnost kao važan faktor navodi 30 ispitanika, a njih 33 kao iznimno važan. No bitno je istaknuti kako je 20 ispitanika indiferentno prema istoj (Grafikon 5). Rezultati provedenog primarnog istraživanja ukazuju kako su vremenski uvjeti, dostupnost, jednostavnost korištenja kao i blizina stanice najvažniji faktori koji utječu na korištenje usluge javnog prijevoza.

Ispitanici su ocjenama od 1-5 (1 - u potpunosti nezadovoljan, 5 - u potpunosti zadovoljan) iskazali stupanj zadovoljstva cijenom usluge, jednostavnošću korištenja, dostupnošću usluge, blizinom stanice (taxi, tramvajske, autobusne, željezničke), osjećajem sigurnosti kod pružene usluge javnog prijevoza te udobnošću. Ocjenjujući cijenu usluge 43 ispitanika je navelo kako je zadovoljno visinom iste dok ih je 16 navelo kako je u potpunosti zadovoljno. Čak 68 ispitanika je ili zadovoljno ili u potpunosti zadovoljno jednostavnošću korištenja usluge. Analizirajući podatke o stupnju zadovoljstva korisnika te uspoređujući s podacima za ocjenu dostupnosti usluge vidljivo je kako su vrlo slični kao i kod jednostavnosti korištenja. Blizinu stanice (taxi, tramvajske, autobusne, željezničke) je 39 ispitanika ocijenilo ocjenom vrlo dobar, dok njih 25 je u potpunosti zadovoljno tim faktorom. Sigurnost javnog prijevoza ocijenjena je ocjenom vrlo dobar od strane 35 ispitanika dok je njih 17 dalo ocjenu izvrstan. Manji broj ispitanika, njih 6 je negativno ocijenio sigurnost dok je njih 16 dalo ocjenu dovoljan. Stupanj zadovoljstva korisnika pruženom uslugom javnog prijevoza nizak kada se radi o udobnosti. Tako je 31 ispitanik ocijenio ocjenom dovoljan udobnost, dok se njih 12 uopće ne slaže te je negativno ocijenilo udobnost.

Grafikon 6. Preporuka ispitanika za korištenje usluga javnog prijevoza

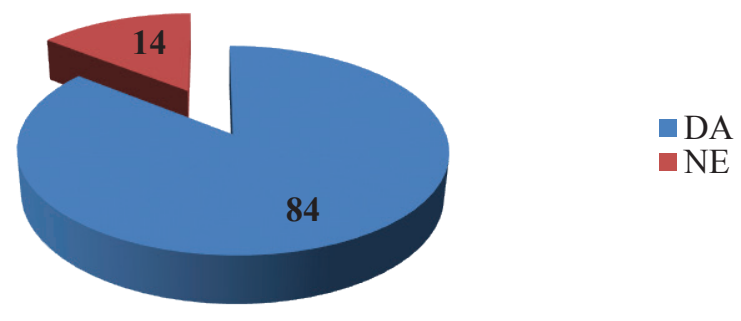

Izvor: primarno istraživanje

Čak 84 ispitanika, odnosno 85,9\%, preporučilo bi korištenje usluge javnog prijevoza. Navedeno ukazuje kako su ispitanici, uvažavajući činjenicu da određeni nedostaci postoje, u velikoj mjeri zadovoljni uslugom javnog prijevoza.

Analizom dobivenih odgovora ispitanika glede osjećaja sigurnosti kod korištenja usluga javnog prijevoza (navedeno odnosi na gradsko-prigradsku željeznicu, TAXI 
službu, tramvaj i autobus), razvidno je kako se putnici najsigurnije osjećaju kod korištenja usluge tramvajskog prijevoza, koji slijedi autobusni i taxi prijevoz dok se najmanje sigurno osjećaju kod korištenja usluge javnog prijevoza u gradsko-prigradskoj željeznici. Nadalje ispitanici su odgovarali na pitanje smatraju li kako se dovoljno ulaže u sigurnosne mjere u sustavu javnog prijevoza te da li je potrebno značajnije ulagati u sigurnosne mjere u sustavu javnog prijevoza. Ispitanici smatraju da se ne ulaže dovoljno u sigurnost javnog prijevoza te da je potrebno značajnije ulagati u sustav javnog prijevoza.

Glede mišljenja ispitanika o tome da li bi u slučaju terorističkog napada na sustav javnog prijevoza hitne službe pravovremeno reagirale, njih 29 smatra da bi sigurnosne službe pravovremeno reagirale, a njih 10 se u potpunosti slaže. Uopće se ne slaže se s tom tvrdnjom njih 24, a ne slaže se s tom tvrdnjom njih 19. Od 99 ispitanika njih 58 je navelo kako se ne boje koristiti usluge javnog prijevoza zbog straha od terorističkog napada, dok ih je 18 navelo kako se boji koristiti usluge javnog prijevoza zbog straha od terorističkog napada. Stoga se može zaključiti kako se ispitanici u Republici Hrvatskoj ne boje koristiti usluge javnog prijevoza zbog straha od terorističkih napada. Glede tvrdnje da li u trenucima kada su bili izvršeni teroristički napadi na sustav javnog prijevoza (Madrid, London, ...) neko vrijeme nisu koristili usluge istog u Republici Hrvatskoj 58 ispitanika se uopće ne slaže s tom tvrdnjom, a njih 14 se ne slaže. Samo 3 ispitanika se slaže u potpunosti dok ih se 8 slaže. O navedenom nema mišljenje 15 ispitanika. Sukladno tome može se zaključiti kako korisnici usluga javnog prijevoza u Republici Hrvatskoj nisu apstinirali od korištenja usluga javnog prijevoza kao refleksije terorističkih napada $u$ drugim državama.

33 ispitanika smatraju kako je sigurnost na stanicama u sustavu javnog prijevoza u potpunosti nezadovoljavajuća, dok ih 9 navodi kako nije zadovoljavajuća. Samo 8 ispitanika smatra kako je sigurnost na stanicama u potpunosti zadovoljavajuća. Obzirom da ovaj podatak u velikom mjeri ovisi i o kojoj se vrsti javnog prijevoza radi buduća istraživanja bi trebalo detaljnije provesti u tom smjeru. Glede stava ispitanika o adekvatnoj raspoređenosti zaštitara na ključnim mjestima, 38 ispitanika se uopće ne slaže s tom tvrdnjom dok se 24 ispitanika slaže s tom tvrdnjom. U potpunosti se slaže s tom tvrdnjom 5 ispitanika, a njih 8 se slaže. Indifirentnost prema navedenom su iskazala 23 ispitanika. Temeljem rezultata može se generalno zaključiti kako ispitanici smatraju da na ključnim mjestima nije raspoređen adekvatan broj zaštitara. Za tvrdnju u upitniku „Osjećam se sigurno jer znam da je sustav javnog prijevoza pod kontinuiranim nadzorom", čak 30 ispitanika nema mišljenje, dok se 28 ispitanika ne slaže odnosno njih 21 se uopće ne slaže sa istom. U potpunosti se slaže s ovom tvrdnjom samo 4 ispitanika, a njih 15 se slaže.

Opravdano je za zaključiti da su podaci ovakvi jer ispitanici nemaju dovoljno informacija o samom sustavu nadzora niti funkcioniranju istog te nisu u mogućnosti na temelju nedostatnih informacija formirati mišljenje. Također za tvrdnju da svjetla i svjetlosna signalizacija omogućuju viši stupanj sigurnosti u sustavu javnog prijevoza čak 31 ispitanik nema mišljenje. Njih 25 se slaže sa ovom tvrdnjom, a njih 13 se u potpunosti slaže. Uopće se ne slaže s ovom tvrdnjom 15 ispitanika, dok se 14 ispitanika ne slaže. Može se zaključiti kako kod ove tvrdnje mišljenje korisnika ide u prilog tvrdnji da svjetla 
i svjetlosna signalizacija omogućuju viši stupanj sigurnosti u sustavu javnog prijevoza o čemu se ispitanici mogu iskustveno uvjeriti prilikom korištenja sustava javnog prijevoza.

Grafikon 7. Mišljenje ispitanika o potrebi povećanja stupnja sigurnosti u sustavu javnog prijevoza u Republici Hrvatskoj

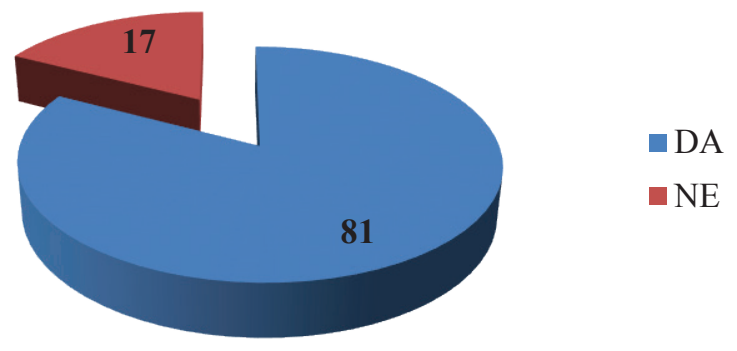

Izvor: izrada autora na temelju prikupljenih primarnih podataka

Na grafikonu 7 vidljivo je kako čak 81 ispitanik, odnosno $82,7 \%$, smatra da u Republici Hrvatskoj postoji potreba za povećanjem stupnja sigurnosti u sustavu javnog prijevoza. Njih 17, odnosno 17,3\%, smatra da nije potrebno povećati stupanj sigurnosti u sustavu javnog prijevoza.

\subsection{Ograničenja i preporuke za buduća istraživanja}

U svrhu izrade ovog rada provedeno je i primarno istraživanje. Bitno je istaknuti kako provedeno istraživanje ima određena ograničenja. Iako je cilj bio obuhvatiti što veći broj ispitanika različitih demografskih karakteristika, $\mathrm{u}$ istraživanju je sudjelovalo ukupno 99 ispitanika te se stoga na temelju istih teško može generalizirati za cijelu Republiku Hrvatsku.

Istraživanje se je provodilo online, preciznije putem Google obrasca te je upravo navedeno sigurno doprinijelo tome da je najveći dio ispitanika bio starosti od 18 do 35 godina. Navedeno je u skladu s činjenicom da su upravo osobe mlađe dobi sklonije upotrebi Interneta. Stoga je ovim načinom prikupljanja primarnih podataka starija populacija zapostavljena, odnosno osobe koje nemaju pristup Internetu ili ne raspolažu znanjem za korištenjem s istim.

Preporuka za buduća istraživanja bila bi da se ista ne provode samo putem Interneta, već i stupanjem u izravni kontakt $\mathrm{s}$ ispitanicima. Obzirom da se starija populacija u velikoj mjeri koristi uslugama javnog prijevoza, navedeno bi svakako moglo pomoći u utvrđivanju njihovih stavova, ali i omogućiti da se utvrdi postoje li razlike u stavovima obzirom na dob ispitanika. Provođenjem primarnog istraživanja fizičkim putem, omogućilo bi se ispitanicima svih dobnih skupina sudjelovanje, ali i onih koji nemaju pristup Internetu. Također, kao što je već i bilo ranije istaknuto u radu, potrebno bi bilo provesti pojedinačna istraživanja fokusirana na pojedinu vrstu javnog prijevoza 
(tramvaj, uspinjača, željeznica i dr.) kako bi se potom moglo utvrditi postoje li značajnije razlike među vrstama u javnom priejvozu.

\section{ZAKLJUČAK}

Tijekom posljednjih godina terorizam je postao stvarnost u mnogim europskim zemljama predstavljajući prijetnju našem načinu života. Javni prijevoz jedna je od čestih meta terorističkih aktivnosti te se je u skladu s Akcijskim planom za potporu zaštiti javnih prostora Europska komisija obvezala podržati države članice Unije u nastojanju da se takvi napadi preveniraju imajući na umu da je takva prevencija i zaštita javnih prostora prvenstveno u nadležnosti država članica. U kontekstu javnog prijevoza poseban naglasak je na sigurnosti putnika u javnom prijevozu na način da se preveniraju učinci prijetnji te da se kontinuirano radi na osmišljavanju rješenja za prevenciju i ublažavanje učinaka terorističkih aktivnosti kroz kontinuirano jačanje regulatornog okvira, predlaganje smjernica za zemlje EU, gradske vlasti i operatore. Financiranje od strane Europske unije pruža još jedan način podrške državama članicama u zaštiti javnih prostora, oslanjajući se na stručnost i najbolju praksu u državama članicama i jačanju prekogranične suradnja.

Sigurnost javnog prijevoza u uskoj je vezi sa sigurnosti javnih površina. U tom smislu pitanje je odgovornosti lokalne uprave, gradskih tijela kao i tijela nadležnih za lokalni javni prijevoz bez obzira da li se radio o javnim ili privatnim prijevoznicima. Te se odgovornosti ne mogu razdvojiti u današnjem društvu, čak iako je javni prijevoz u privatnom vlasništvu. Preporuka za praksu jest izrada modernog sigurnosnog plana javnog prijevoza u izradi kojeg moraju sudjelovati svi dionici na razini od lokalne uprave, prijevoznika pa do poduzeća (trgovine, restorani, trgovački centri i sl.) i naravno putnika. $\mathrm{Za}$ borbu protiv terorizma prvo je potrebno znati tko je neprijatelj, a to je područje specijalista koji imaju specifična znanja koja moraju ostati povjerljiva. Ovo pitanje stoga leži izvan područja nadležnosti operatora javnog prijevoza. Višoj razini sigurnosti u javnom prijevozu može doprinijeti primjerice korištenje javnog prijevoza izvan prijevozne "špice", kraće vrijeme čekanja, niži troškovi sanacije štete, veći angažman obučenog osoblja i manje distrakcije prilikom pružanja usluga. Uz to edukacija korisnika usluge javnog prijevoza, putnika odnosno svih građana usmjerena na sprječavanje terorističkih napada također može biti od koristi zajednici. Imajući na umu da javni prijevoz koristi prostore kroz koje svakodnevno prolaze tisuće ljudi, moraju postojati u današnje vrijeme i razvijeni oblici kontrole.

Rezultati provedenog primarnog istraživanja pokazuju da u Republici Hrvatskoj ne postoji visoka razina osviještenosti i percepcije o potencijalnim terorističkim napadima u javnom prijevozu. Također nije prisutan u velikoj mjeri niti strah od terorističkih napada u javnom prijevozu. Korisnicima usluge javnog prijevoza primarni su faktori jednostavnost korištenja usluge, dostupnost, cijena, način plaćanja te blizina stanice. Istraživanje je pokazalo kako je sigurnost korisnicima usluge javnog prijevoza važan faktor iako nije primarno u direktnoj vezi s potencijalnim terorističkim aktivnostima te da je potrebno povećati razinu sigurnosti posebice na stanicama i stajalištima. 
Slijedom svega navedenog u rješavanju problema terorističkih aktivnosti $u$ javnom prijevozu, najprije je potrebno steći uvid u njegove uzroke, mjesta na kojima se događa, glavne oblike i kako se razvija da bi mogli utvrditi primarne ciljeve zaštitnih mjera. Infrastruktura i svi oblici prijevoznih sredstava također moraju biti bolje dizajnirani kako bi bili manje osjetljivi na posljedice terorističkih aktivnosti. Korištenje suvremenih nadzornih i informacijskih tehnologija također može pomoći u prevenciji. Svi dionici javnog prijevoza trebaju sinergijski djelovati te postaviti zajedničke ciljeve u obliku mjera koje bi onda aktivno poduzimali svi. Potrebna je edukacija svih dionika, a posebice korisnika usluge javnog prijevoza, putnika. Aktivna participacija je od iznimne važnosti jer kao jedan od oblika prevencije i borbe protiv terorističkih aktivnosti jest potreba stvaranja te poticanje osjećaja građanskog zajedništva i odgovornosti prvenstveno u prevenciji potencijalnih terorističkih aktivnosti.

\section{LITERATURA:}

1. Akca, H., Ela, M. (2017). Economic, Financial and Fiscal Effects of Terrorism: A Literature Review Dostupno na: https://www.researchgate.net/publication/331593898_Economic Financial_and Fi scal_Effects_of_Terrorism_A_Literature_Review (12.06.2021.).

2. Bardwell, H. Mohib, I. (2021). The Economic Impact of Terrorism from 2000 to 2018, Peace Economics, Peace Science and Public Policy, 27(2), str. 227-261. DOI: https://doi.org/10.1515/peps-2020-0031

3. Ciganik, L., Balasicova, I. (2008). Protection and Defence of Railway Transport against International Terrorism, Communications-Scientific letters of the University of Zilina, 10(1), str. 40-44. Dostupno na: http://komunikacie.uniza.sk/index.php/communications/article/view/1029 (15.05.2021.).

4. Currie, G., Delbosc, A., Mahmoud, S. (2013). Factors influencing young peoples' perceptions of personal safety on public transport, Journal of public transportation, 16(1), str. 1-19. DOI: http://doi.org/10.5038/2375-0901.16.1.1

5. Državni zavod za statistiku Republike Hrvatske (14.05.2021.). Transport u prvom tromjesečju 2021. Zagreb: Državni zavod za statistiku. Dostupno na: https://www.dzs.hr/Hrv_Eng/publication/2021/05-01-01_01_2021.htm (03.07.2021.).

6. Duduta N, Adriazola C, Hidalgo D, Lindau LA, Jaffe R. (2012). Understanding the road safety impact of high performance BRT and busway design features, Transportation Research Record, 2317(1), str.8-14. DOI: https://doi.org/10.3141\%2F2317-02

7. Duduta, N., Adriazola, C., Hidalgo, D., Lindau, LA., Jaffe, R. (2014). Traffic safety in surface public transport systems: a synthesis of research, Public Transportation, 7(2), str. 121-137. DOI: https://doi.org/10.1007/s12469-014-0087-y

8. Esper, P. Bond, C. (2005). Making Public Transport Safer, Structural Engineer, 83(15), str. 12-14. 
9. European Commission (10.11.1997.). Treaty of Amsterdam amending the treaty on European Union, the treaties establishing the European Communities and certain related acts, Official Journal of the European Communities, No. C340/1. Dostupno na:

https://eur-lex.europa.eu/legalcontent/EN/TXT/PDF/?uri=CELEX:11997D/TXT\&from=HR (25.09.2021.).

10. European Commission (2018). Dostupno na: https://ec.europa.eu/homeaffairs/sites/default/files/what-we-do/policies/european-agendasecurity/20171018_action_plan_to_improve the protection_of public_spaces_en. pdf(24.05.2021.).

11. European Commission (2020). A Counter-Terrorism Agenda for the EU: Anticipate, Prevent, Protect, Respond. Dostupno na: c.europa.eu/homeaffairs/sites/default/files/pdf/09122020_communication_commission_european_pa rliament the council_eu_agenda_counter_terrorism_po-2020-9031_com2020795 en.pdf (24.05.2021.).

12. European Commission (27.11.2001.). Proposal for a Council framework Decision on combating terrorism /* COM/2001/0521 final - CNS 2001/0217*/, Official Journal $332 \quad$ E. $\quad$ Dostupno na: lex.europa.eu/LexUriServ/LexUriServ.do?uri=CELEX:52001PC0521:EN:HTML (12.09.2021.).

13. European Commission (N/A). Mobility and Transport. Security and Safety. Dostupno na: https://ec.europa.eu/transport/themes/security en (27.04.2021.).

14. European Commission QUATTRO Final Report (1998). Synthesis and Recommendations. Dostupno na: http:/europa.eu.int/comm/transport/ extra/final_reports/urban/quattro.pdf. (24.05.2021.).

15. EUROPOL (2020). European Union Terrorism Situation and Trend report 2020, The Hague; European Union Agency for Law Enforcement Cooperation. Dostupno na: https://www.europol.europa.eu/activities-services/main-reports/europeanunion-terrorism-situation-and-trend-report-te-sat-2020 (04.06.2021.).

16. Europski parlament (03.11.2020.). Terorizam u EU-u: Napadi, stradanja i uhićenja u 2019.. Dostupno na: https://www.europarl.europa.eu/news/hr/headlines/security/20180703STO07125/te rorizam-u-eu-u-napadi-stradanja-i-uhicenja-u-2019

17. Friman, M., Lättman, K., Olsson, L. E. (2020). Public transport quality, safety, and perceived accessibility, Sustainability, 12(9), 3563. DOI: https://doi.org/10.3390/su12093563

18. Gaibulloev, K., Sandler, T., Santifort, C. (2012). Assessing the evolving threat of terrorism, Global Policy, 3(2), str. 135-144. DOI: https://doi.org/10.1111/j.17585899.2011.00142.x

19. Global Indeks Terorism, (2019). Dostupno na: https://www.visionofhumanity.org/maps/global-terrorism-index/\#/ (15.06.2021.).

20. Global Terorism Database (2021). Dostupno na: https://www.start.umd.edu/gtd/ (15.06.2021.).

21. https://eur-lex.europa.eu/legal-content/HR/TXT/?uri=CELEX\%3A52018DC0470 (15.07.2021). 
22. https://www.macrotrends.net/cities/22860/london/population (13.07.2021.).

23. Litman, T. (2016). "Evaluating Public Transit Benefits and Costs" https://web.archive.org/web/20170110202923/http://www.vtpi.org/tranben.pdf (26.06.2021.).

24. Litman, Todd. 2005. Terrorism, Transit and Public Safety: Evaluating the Risks . Journal of Public Transportation, 8(4): 33-45. DOI: http://doi.org/10.5038/23750901.8.4.3

25. Matsika, E., O’Neill,C., Battista, U., Khosravi, M., Laporte, A., Munoz, E., (2016). Development of risk assessment specifications for analysing terrorist attacks vulnerability on metro and light rail systems, Transportation research procedia, vol. 14, str. 1345-1354. DOI: https://doi.org/10.1016/j.trpro.2016.05.207

26. McLeod, Sam (2017). Urban Public Transport: Planning Principles and Emerging Practice, Journal of Planning Literature, 32(3), str. 223-239. DOI: https://doi.org/10.1177\%2F0885412217693570

27. Narodne novine (2018). Zakon o prijevozu u cestovnom prometu, br. 41, Zagreb: Narodne novine d.d..

28. Narodne novine. Zakon o sigurnosti prometa na cestama, Zagreb: Narodne novine d.d. Dostupno na: https://www.zakon.hr/z/78/Zakon-o-sigurnosti-prometa-nacestama.

29. Park, W. A. (2020). A Study on the Improvement of Terorism response in Subway Crisis and Public Transportation, International journal of terrorism \& national security, 5(1), str. 48-59.

30. Prodan, T., (2014). Komparativna analiza protuterorističkih strategija Sjedinjenih američkih država i Europske unije, Polemos, 17(1-2), str. 49-69.

31. Rajsman, M. (2017). Tehnologija prijevoza putnika u cestovnom prijevozu. Dostupno na: http://files.fpz.hr/Djelatnici/mrajsman/Marijan-RajsmanTehnologija-prijevoza-putnika-u-cestovnom-prometu.pdf (26.06.2021.).

32. Segell, G. M. (2006). Terrorism on London public transport, Defense \& Security Analysis, 22(1), str. 45-59. DOI: https://doi.org/10.1080/14751790600577132

33. Shvetsov, A. V., Shvetsov, M. A. (2019). A Fast-Track Method for Assessing the Risk of a Terrorist Attack on Transportation Facilities, European Journal for Security Research, 4(2), 265-271. DOI: https://doi.org/10.1007/s41125-019-00044$\underline{\mathrm{x}}$

34. Stjernborg, V., Mattisson, O. (2016). The Role of Public Transport in Society-A Case Study of General Policy Documents in Sweden, Sustainability, 8, 1120. DOI: https://doi.org/10.3390/su8111120

35. Useche, S. A., Gómez, V., Cendales, B., Alonso, F. (2018). Working conditions, job strain, and traffic safety among three groups of public transport drivers, Safety and health at work, 9(4), str. 454-461. DOI: https://doi.org/10.1016/j.shaw.2018.01.003

36. Vuchic, V. (2007). Urban transit systems and technology. Hoboken, New Jersey: John Wiley \& Sons Inc..

37. Wagner, D., Lehnigk, N. (2010). Sicherheit im Öffentlichen Personennahverkehr des Landes Brandenburg. Brandenburgisches Institut für Gesellschaft und Sicherheit. 
38. Zaštita.info.(2019). Dostupno na: https://zastita.info/hr/novosti/sigurnost-i-zastitau-javnom-prijevozu,25672.html (16.06.2021.).

39. Zavada, J. B., Nikšić, M., Kovačević, D. (2002). Railway Development from the Aspect of Environmental Protection. Promet-Traffic\&Transportation, 14(4), str. 167-171. 


\title{
IMPACT OF TERRORISM ON SAFETY OF PUBLIC TRANSPORTATION IN EUROPE
}

\author{
Ante Vuletić, Lucijan Horak \& Marija Jurčević
}

\begin{abstract}
Summary
Terrorism is a method for achieving certain political goals through violence, criminal activities and endangerment of large social groups. The basic characteristic of these activities are spreading fear and terror among the population. Terrorism has become an every-day challenge on global level and the risk of terrorism as a form of political risk is becoming more and more a part of system models for risk assessment. Activities connected with terrorism have not skipped public transportation either. This branch of transportation has been of special interest to those involved in terrorist activities in the last decade. For the people who are planning such activities, public transportation is an ideal target because there are millions of commuters who use public transportation services every day and it is very challenging to keep all the segments secure and equally protected. In public transportation, high level of protection can be developed at obvious control points. For everyone involved, making all segments of public transportation safe is a huge challenge, because all segments have to remain available to users. Unlike airports, where there are control points set up, at bus and train stops, there are no preconditions for providing high level of protection. To achieve the goal of this paper, an analysis of the current studies on terrorist attacks was conducted, along with the primary research. It is crucial to work on implementing safety measures that can impede terrorist activities, and heighten the probability for the terrorists to be uncovered and identified.
\end{abstract}

Keywords: public transport; terorism; effect; safety; European Union. 